\title{
ANALISIS KEBUTUHAN TATA KELOLA TATA LAKSANA LABORATORIUM IPA SMP DI KABUPATEN BULELENG
}

\author{
I Dewa Putu Subamia', Putu Artawan ${ }^{2}$, I.G.A.N. Sri Wahyuni ${ }^{3}$ \\ ${ }^{1}$ Jurusan Pendidikan Kimia, ${ }^{2,3}$ Jurusan Pendidikan Fisika, Fakultas MIPA \\ Universitas Pendidikan Ganesha \\ Singaraja Indonesia \\ e-mail: ajiram_dewa@yahoo.com
}

\begin{abstract}
Abstrak
Permasalahan yang diangkat dalam penelitian ini adalah rendahnya kualitas tata kelola dan tata laksana laboratorium IPA SMP di Kabupaten Buleleng. Penelitian ini bertujuan untuk melakukan analisis kebutuhan pengembangan perangkat Tata Kelola Tata Laksana Laboratorium IPA di SMP. Populasi penelitian mencakup seluruh SMP Negeri dan Swasta di Kabupaten Buleleng. Sampel penelitian ditetapkan dengan teknik cluster sampling mempertimbangkan status sekolah, keadaan sosial, dan alamiahnya. Jumlah sekolah sampel sebanyak 9, masingmasing 3 dari setiap kawasan kabupaten Buleleng; dengan melibatkan kepala sekolah, pengelola lab, guru IPA, dan laboran sebagai subjek penelitian. Data penelitian dikumpulkan dengan daftar isian, pedoman observasi, pedoman wawancara, penilaian kinerja, dan angket; serta dianalisis secara deskriptif,dilengkapi cross-check data dari sumber data. Kesimpulan hasil analisis: sekolah menghadapi beberapa kendala dan hambatan untuk melaksanakan tata kelola tata laksana laboratorium, yaitu: keterbatasan ruang dan fasilitas laboratorium, keterbatasan alat-alat dan bahan-bahan praktikum, ketidaktersediaan tenaga laboran, belum ada SOP tata kelola tata laksana laboratorium, ketidakmampuan guru mengelola pembelajaran sesuai dengan ketersediaan waktu efektif, hambatan psikologis guru yang belum merasa puas jika tidak banyak berceramah, dan keterbatasan laboratorium IPA SMP,(2)artikel ilmiah,dan (3) proseding pada seminar ilmiah institusi.dana pendukung operasional. Luaran penelitian berupa (1) perangkat SOP tata kelola dan tata laksana laboratorium IPA SMP,(2)artikel ilmiah,dan (3) proseding pada seminar ilmiah institusi.
\end{abstract}

Kata kunci: tata kelola, tata laksana, laboratorium

\begin{abstract}
The issues raised in this study is the low quality of governance and management of junior high school science lab in Buleleng regency. This study aims to analyze the development needs of Governance in the Science Laboratory Procedure SMP. The study population includes all public and private junior high school in Buleleng regency. Study sample defined by cluster sampling technique to consider the status of the school, the social, and natural. Number of sample schools by 9,3 each from each area of Buleleng regency; involving principals, managers lab, a science teacher, and the laboratory as a research subject. Data were collected to a questionnaire, observation, interview guides, performance assessment, and
\end{abstract}


questionnaires, as well as analyzed descriptively, has cross-checked the data from the data source. Conclusion The results of the analysis: the school faced some obstacles and barriers to implementing governance and management laboratories, namely: the limitations of space and laboratory facilities, limitations of the tools and lab materials, unavailability of laboratory personnel, there is no Standard Operational Procedure of laboratory governance and management, incompetence teacher to manage learning within the available time effectively, psychological barriers that teachers do not feel satisfied if there is a lot of preaching, and operational support funding limitations. Research outputs in the form of (1) the SOP governance and management of junior high science lab, (2) scientific articles, and (3) Proceedings of the scientific seminar institution.

Keywords: governance, management, laboratory

\section{PENDAHULUAN}

Sebagai bagian integral proses pembelajaran IPA, laboratorium sekolah memiliki fungsi yang sangat strategis dalam pencapaian kompetensi siswa. Kegiatan laboratorium akan sangat mendukung pelaksanaan proses pembelajaran IPA, terutama karena IImu Pengetahuan Alam dibangun dari berbagai eksperimen. Disamping merupakan salah satu aspek penilaian penjaminan mutu pendidikan nasional (PP No. 19 Tahun 2005), pentingnya praktikum dalam pendidikan IPA juga mensyaratkan bahwa keberadaan laboratorium IPA di SMP benar-benar penting. PP Nomor 19 Tahun 2005 tentang Standar Nasional Pendidikan Pasal 42 ayat (2) serta Pasal 43 ayat (1) dan ayat (2) mensyaratkan bahwa pendidikan wajib memiliki prasarana termasuk ruang laboratorium untuk menunjang proses pembelajaran yang teratur dan berkelanjutan.

Demikian pula Badan Standar Nasional Pendidikan (BSNP, 2006) menyatakan bahwa sekolah harus memiliki sarana prasarana laboratorium disamping perabot dan peralatan pendidikan lainnya. Keberadaan peralatan dan bahan laboratorium dalam pembelajaran IPA merupakan sarana yang harus diupayakan guna meningkatkan mutu pembelajaran IPA di sekolah. Oleh karena itu untuk meningkatkan efesiensi dan efektifitas, laboratorium harus dikelola dan dimanfaatkan dengan sebaik-baiknya.

Dalam proses belajar mengajar IPA, laboratorium dapat difungsikan sebagai tempat: a) menemukan masalah, b) memecahkan masalah, c) memeperdalam pengertian suatu fakta, d) menemukan berbagai pengertan atau fakta, e) melatih kebiasaan dan keterampilan ilmiah, dan f) mendididk anak menjadi cermat, kritis dan cekatan (Sidharta, A. dkk. 2007).

Menurut Mundilarto (2007), tujuan penggunaan laboratorium IPA diantaranya adalah:

mengembangkan kompetensi siswa, baik aspek kognitif, psikomotor, maupun afektif; (2) mengembangkan kompetensi sosial siswa; (3) mengembangkan keterampilan siswa dalam hal pengamatan, pencatatan data, dan penggunaan alat; (4) melatih siswa bekerja cermat dan disiplin; (5) mengembangkan daya pikir siswa melalui analisis dan penafsiran hasil percobaan; (6) mngembangkan kejujuran dan kerjasama serta rasa tanggung jawab.

Jurnal Pendidikan Indonesia |447 
Koretsky, M (2011), menyebutkan dalam hasil penelitiannya bahwa secara signifikan respon siswa meningkat pada kelompok yang diberikan model eksperimen. Pemanfaatan laboratorium dalam pembelajaran dapat meningkatkan hasil belajar siswa secara signifikan. Novianti, N.R. (2011), meyebutkan bahwa belajar IPA akan menghasilkan produk IPA itu sendiri, cara berpikir ilmiah, dan sikap ilmiah. Ketiga hal tersebut dipelajari melalui kerja ilmiah yang dilakukan melalui kegiatan eksperimen di laboratorium. Untuk keperluan ini harus tersedia sarana dan prasarana laboratorium serta sistem pengelolaan yang baik dan benar.

Krajcik, J. S. and Banaszak Holl, M. M. (2012), menyebutkan bahwa salah satu prasyarat dalam pembelajaran/praktikum IPA adalah pemanfaatan laboratorium. Oleh sebab itu diperlukan adanya sistem pengelolaan atau manajemen laboratorium IPA yang baik. Hal senada juga dikemukakan oleh Berte, L.M. (2012), bahwa pengelolaan laboratorium memiliki peranan penting dalam mewujudkan efektivitas pembelajaran.

Lebih jauh dijelaskan bahwa untuk meningkatkan efesiensi dan efektifitas, laboratorium harus dikelola dan dimanfaatkan dengan baik. Dari tujuan pembelajaran IPA di SMP, sebagian besar tujuan tersebut hanya dapat dicapai secara optimal bila guru menggunakan laboratorium sebagai sarana dan prasarana belajar siswa (Sulastri, S. 2008).

Oleh karenanya, perlu upaya pemberdayaan tata kelola dan tata laksana laboratorium untuk meningkatkan daya dukung laboratorium terhadap kualitas pembelajaran IPA.

Namun kenyataannya, efektivitas dan efisiensi laboratorium IPA SMP di Kabupaten Buleleng masih sangat rendah. Data hasil wawancara yang diperoleh dari tenaga laboratorium IPA SMP di Buleleng menunjukkan bahwa frekuensi penggunaan laboratorium IPA SMP di Kabupaten Buleleng masih rendah.

Sidharta,A.,dkk.(2007)

menyebutkan fakta di lapangan banyak kendala pemanfaatan laboratorium sebagai sarana praktikum. Hasil penelitian Anna (2007), melaporkan bahwa umumnya para guru merasa kurang menguasai teknik mengelola alat, bahan dan limbah laboratorium. Praktek sangat minim, rata-rata 3-5 kali/3 tahun. Keadaan ini memang sangat memprihatinkan, karena ternyata berdampak lanjut terhadap pemahaman siswa terhadap kemampuan dasar berlaboratorium.

Subamia I.D.P. (2012.), menemukan bahwa rendahnya keterampilan dasar berlaboratorium berkorelasi terhadap rendahnya frekuensi penggunaan laboratorium dan terlantarnya keberadaan laboratorium IPA SMP. Selanjutnya akan berpengaruh terhadap proses dan hasil belajar IPA. Hal tersebut memberi sinyalemen kuat bahwa pemberdayaan pengetahuan dan keterampilan pengelolaan dan pelaksanaan kegiatan dilaboratorium bagi staf/tenaga laboratorium sangatlah penting. Observasi di beberapa laboratorium SMP di kabupaten Buleleng diketahui keberadaan laboratorium IPA di SMP sebagian besar "terlantarkan". Alat-alat yang ada 
banyak yang tidak tertangani dengan baik, tidak terawat, dan tidak dapat difungsikan secara optimal. Hal ini menunjukkan bahwa pengelolaan, pemanfaatan dan pemberdayaan laboratorium IPA SMP di Kabupaten Buleleng belum memenuhi standar mutu yang dipersyaratkan (Subamia, I.D.P, 2011).

Berdasarkan hasil wawancara dan kunjungan di beberapa laboratorium SMP di kabupaten Buleleng dapat diidentifikasi beberapa permasalahan sebagai berikut:1) frekuensi penggunaan laboratorium IPA SMP di Kabupaten Buleleng masih rendah, 2) sebagian besar guru IPA masih mengalami masalah untuk melakukan praktikum tentang topik-topik tertentu karena alasan terbatasnya jumlah dan/atau jenis alat yang tersedia, 3) laboratorium IPA tidak dikelola dengan baik, 4) umumnya tenaga pengelola laboratorium IPA tidak menerapkan tata kelola tata laksana laboratorium dengan baik.

Bertolak dari fenomena di atas maka untuk mewujudkan layanan laboratorium yang profesional, kondusif, efektif, efisien, dan produktif maka upaya pengembangan tata kelola tata laksana laboratorium IPA SMP di Kabupaten Buleleng mutlak diperlukan.

Rumusan permasalahan dalam penelitian ini adalah sebagai brikut: a) Dimensi-dimensi pengelolaan apa saja yang berpengaruh terhadap pemberdayaan tata kelola tata laksana laboratorium IPA SMP? b) Bagaimana gambaran kondisi daya dukung SDM dan sarana-prasarana laboratorium untuk menunjang kegiatan pembelajaran IPASMP di Kabupaten Buleleng? c) Bagaimanakah gambaran pengelolaan dan pelaksanaan kegiatan laboratorium IPA SMP di Kabupaten Buleleng? d) Bagaimana kompetensi tata kelola tata laksana laboratorium yang dimiliki tenaga laboratorium IPA SMP di Kabupaten Buleleng? e) Bagaimana upaya untuk meningkatkan kualitas tata kelola tata laksana laboratorium IPA SMP di Kabupaten Buleleng?

Secara umum penelitian ini bertujuan untuk meningkatkan tata kelola dan tata laksana laboratorium IPA SMP di Kabupaten Buleleng. Secara spesifik tujuan penelitian ini adalah sebagai berikut. a) Identifikasi dimensidimensi pendukung pemberdayaan tata kelola dan tata laksana laboratorium IPA SMP di Kabupaten Buleleng. b) Menganalisis gambaran kondisi daya dukung SDM dan sarana-prasarana laboratorium untuk menunjang kegiatan pembelajaran IPA-SMP di Kabupaten Buleleng. c) Memperoleh gambaran seperti apa pengelolaan dan pelaksanaan kegiatan laboratorium IPA SMP di Kabupaten Buleleng. d) Mengidentifikasi kompetensi tata kelola tata laksana laboratorium yang dimiliki tenaga laboratorium IPA SMP di Kabupaten Buleleng. e) Melakukan analisis kebutuhan untuk pengembangan kualitas tata kelola tata laksana laboratorium IPA SMP di Kabupaten Buleleng.

Hasil penelitian ini akan memberikan kontribusi positif dalam peningkatan tata kelola dan tata laksana laboratorium IPA SMP. Peningkatan mutu tata kelola tata laksana laboratorium akan bemanfaat untuk peningkatan kualitas pembelajaran IPA di SMP.

Jurnal Pendidikan Indonesia $\mid 449$ 


\section{METODE PENELITIAN}

\section{Rancangan Penelitian}

Penelitian ini dirancang sebagai penelitian deskriptif untuk memperoleh potret tata kelola dan tata laksana laboratorium IPA SMP di Kabupaten Buleleng. Rencana pemecahan masalah dilakukan dengan rancangan penelitian deskriptif untuk memperoleh potret tata kelola dan tata laksana laboratorium IPA SMP di Kabupaten Buleleng. Potret tersebut selanjutnya dijadikan landasan pengembangan standar operasional prosedur (SOP) tata kelola dan tata laksana laboratorium IPA. Rancangan penelitian dapat digambarkan sebagai berikut.

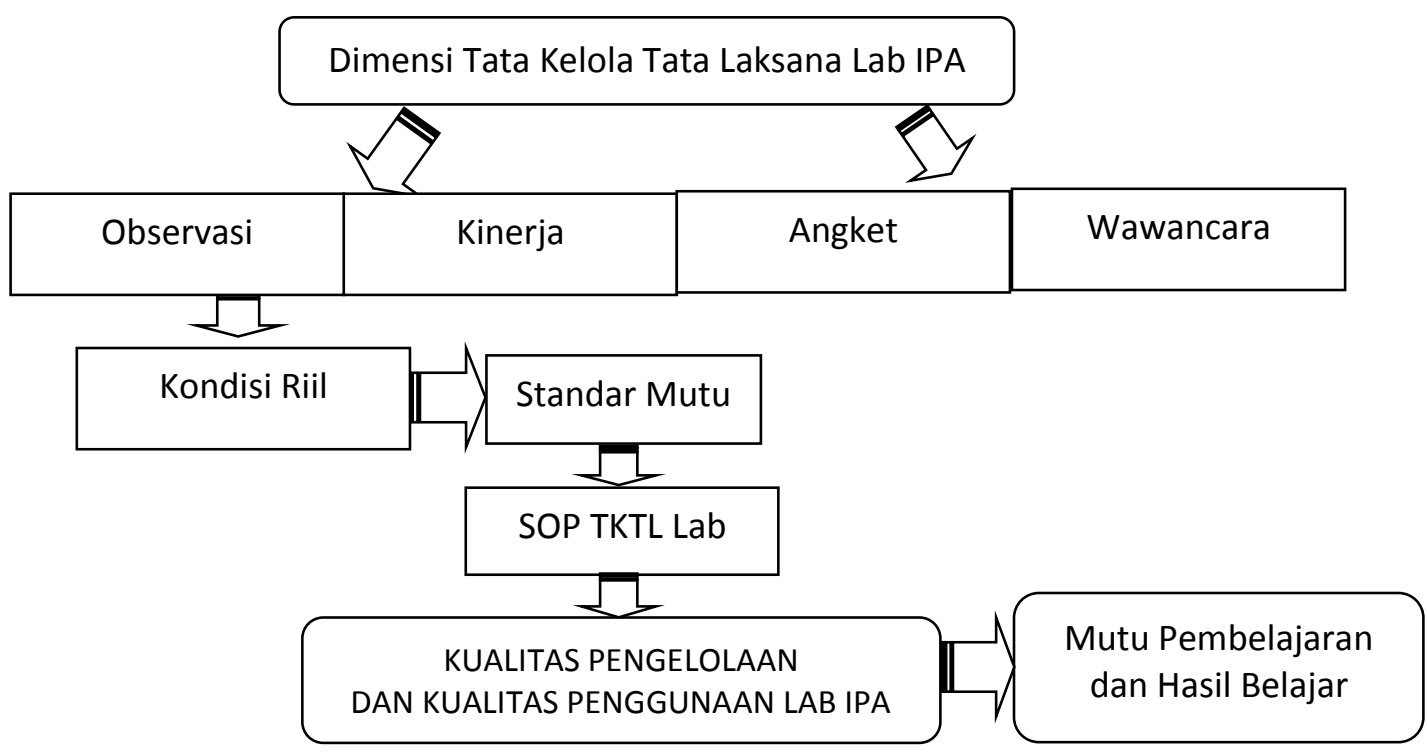

Gambar 1: Skema Rancangan Penelitian

\section{Lokasi Penelitian}

Lokasi penelitian merupakan tempat pelaksanaan penelitian tersebut dilakukan. Lokasi penelitian ini adalah di SMP Negeri dan Swasta di Wilayah Kabupaten Buleleng Provinsi Bali.

Populasi Penelitian. Sesuai dengan permasalahan dalam penelitian ini, maka yang menjadi populasi adalah seluruh SMP Negeri dan Swasta Wilayah Kabupaten Buleleng, yaitu berjumlah 83 SMP yang tersebar di 9 kecamatan.
Sampel Penelitian. Sampel penelitian ditetapkan dengan teknik cluster sampling mempertimbangkan status sekolah, keadaan sosial, dan alamiahnya. Jumlah sekolah sampel sebanyak 9, masing-masing 3 dari setiap kawasan Buleleng. Sekolah sampel: SMP N 2 Singaraja, SMP N 1 Sukasada, SMP N 6 Singaraja, SMP N 3 Seririt, SMP N 4 Banjar, SMP Lab Undiksha, SMP N 4 Kubutambahan, SMP N 5 Tejakula, dan SMP Mutiara Singaraja. 


\section{Subjek dan Objek Penelitian}

Subyek penelitian adalah kepala sekolah, guru IPA, penanggung jawab laboratorium IPA, dan laboran/teknisi lab IPA. Sebagai objek atau peubah yang diukur dalam penelitian adalah dimensi pendukung tata kelola dan tata laksana laboratorium, meliputi: profil kondisi faktor-faktor pendukung pengembangan tata kelola dan tata laksana laboratorium IPA SMP (organisasi laboratorium; administrasi laboratorium (inventarisasi alat dan fasilitas laboratorium, administrasi penggunaan laboratorium, administrasi peminjaman alat-alat laboratorium, administrasi pemeliharaan alat-alat laboratorium); serta keselamatan kerja di laboratorium.

\section{Metode Pengumpulan Data}

Metode yang digunakan dalam penelitian ini adalah deskriptif analitik, dan pendekatan kuantitatif. Instrumen yang digunakan untuk mengumpulkan data adalah sebagai berikut. 1) Pedoman wawancara dengan kepala sekolah dan guru; 2) Angket guru IPA, yang bertujuan untuk mengetahui kesiapan dan pandangan guru berkaitan dengan tata laksana pemanfaatan laboratorium dalam proses pembelajaran memanfaatkan laboratorium; 3)Kuisioner penanggung jawab laboratorium;4) Angket untuk laboran, untuk mengetahui permasalahan-permasalahan dalam persiapan pelaksanaan praktikum; 5) Kuisioner untuk bagian pengadaan sarana dan sumber daya pendidikan; 6 ) Pedoman observasi untuk memperoleh data profil kondisi laboratorium.

\section{Analisis Data}

Data yang dikumpulkan dalam penelitian ini berupa data kualitatif, yang selanjutnya dianalisis secara deskriptif. Metode yang digunakan adalah deskriptif analitik, dan pendekatan kuantitatif.

\section{HASIL DAN PEMBAHASAN}

Pada bagian ini akan dipaparkan data-data yang diperoleh pada penelitian mengacu kepada rumusan permasalahan.

1) Dimensi-dimensipendukung tata kelola dan tata laksana laboratorium IPA SMP mencakup: perencanaan, penataan, pengadministrasian, pengamanan, perawatan, dan pengawasan.

2) Profil kondisi daya dukung SDM dan sarana-prasarana laboratorium untuk menunjang kegiatan pembelajaran IPASMP di Kabupaten Buleleng.

Daya dukung terhadap pembelajaran IPA di SMP yang dikaji dalam penelitian ini mencakup sumber daya manusia (guru dan laboran), fasilitas laboratorium (gedung, alat-alat, dan bahan-bahan praktikum IPA), dan dana.

Keberadaan guru IPA di masingmasing sekolah sampel secara umum sudah memadai. Namun ada beberapa sekolah yang hanya memiliki seorang guru IPA. Berbeda dengan keberadaan guru-guru IPA, keberadaan laboran masih sangat kurang. Dari 9 sekolah sampel, hanya 3 sekolah (33,3\%) didukung oleh laboran. Hasil wawancara dengan kepala sekolah menunjukkan bahwa semua kepala sekolah menyatakan mendukung optimalisasi

Jurnal Pendidikan Indonesia |451 
pemanfatan laboratorioum. Arahan dan kesempatan untuk mengembangkan pengetahuan dan keterampilan bagi guru-guru IPA difasilitasi sepenuhnya. Namun, hasil wawancara dan angket guru-guru menyatakan bahwa guru-guru masih merasa bahwa pemanfaatan laboratorium (praktikum) menjadi beban tambahan karena tidak ada tenaga khusus (laboran) yang diharapkan menyiapkan keperluan praktikum.

Fasilitas laboratorium yang dimiliki sekolah menurut informasi dari kepala sekolah belum memadai. Secara fisik, fasilitas gedung laboratorium yang ada banyak belum memadai. Dari 9 laboratorium yang ada di sembilan sekolah sampel, 5 (55,6\%) di antaranya tidak didukung dengan fasilitas air atau fasilitas yang memadai. Bahkan ada laboratorium yang fasilitas airnya tidak lancar. Fasilitas listrik dan ventilasinya umumnya sudah baik.

Ketersedian alat-alat dan bahan-

bahan IPA di laboratorium, menurut pandangan kepala sekolah, pandangan guru dan pandangan laboran, cukup bervariasi. Sekolah-sekolah yang sudah lama berdiri, ketersedian alat-alat dan bahan-bahan IPA nya sudah cukup memadai untuk keperluan praktikum. Akan tetapi, sekolah-sekolah yang relatif baru berdiri, ketersediaan peralatan dan bahan-bahan IPA nya belum mencukupi (kurang).Senada dengan yang disampaikan oleh guru IPA, petugas laboran juga menyatakan bahwa salah satu kendala utama dalam menyiapkan keperluan praktikum adalah keterbatasan alat dan bahan.

Hasil observasi laboratorium menemukan bahwa ketersediaan alatalat laboratorium yang diperlukan untuk menunjang pembelajaran IPA secara umum tergolong masih kurang.

Hasil wawancara dan angket guru-guru menyatakan bahwa guru-guru masih merasa bahwa pemanfaatan laboratorium (praktikum) menjadi beban tambahan karena tidak ada tenaga khusus (laboran) yang diharapkan menyiapkan keperluan praktikum.

Fasilitas laboratorium yang dimiliki sekolah menurut informasi dari kepala sekolah belum memadai. Dari 9 laboratorium yang ada di sembilan sekolah sampel, 5 (55,6\%) di antaranya tidak didukung dengan fasilitas air atau fasilitas yang memadai. Bahkan ada laboratorium yang fasilitas airnya tidak lancar. Fasilitas listrik dan ventilasinya umumnya sudah baik. Dari hasil angket menunjukkan, semua guru menyampaikan bahwa alat-alat dan bahan-bahan IPA yang ada terbatas, alat-alat dan bahan-bahan yang tersedia hasil droping dari pemerintah banyak tidak sesuai dengan kebutuhan praktikum SMP. Senada dengan yang disampaikan oleh guru IPA, petugas laboran juga menyatakan bahwa salah satu kendala utama dalam menyiapkan keperluan praktikum adalah keterbatasan alat dan bahan.

Rata-rata ketersediaan alat-alat IPA yang diperlukan untuk mendukung pembelajaran IPA sesuai dengan tuntutan kurikulum 2013 berkisar antara $29,4-79,4 \%$ dengan rata-rata 58,8\%. Rata-rata ketersediaan bahan-bahan IPA yang diperlukan untuk mendukung pembelajaran IPA berkisar antara 17,4\% sampai dengan $57,4 \%$ dengan rata-rata $45 \%$.

Menurut pandangan para guru IPA, dana yang dianggarkan sekolah untuk mendukung kegiatan laboratorium

Jurnal Pendidikan Indonesia |452 
IPA sangat terbatas, bahkan ada yang menyampaikan nominalnya hanya ratusan ribu rupiah. Anggaran sebesar itu jelas sangat kurang, dan dalam beberapa kasus tidak terealisasi.

3) Deskripsi pengelolaan dan pelaksanaan kegiatan laboratorium IPA SMP di Kabupaten Buleleng

Pengisian angket oleh 9 orang guru IPA di sekolah sampel menunjukkan, 7 orang $(77,7 \%)$ lebih dominan mengajarkan teori IPA deskriptif dibandingkan proses IPA prosedural eksperimentatif. Sebagian besar guru memperkirakan persentase pembelajaran dengan praktikum dalam satu semester antara $10 \%-25 \%$. Bahkan ada responden yang menyatakan tidak pernah melakukan praktikum. Berarti pemanfaatan laboratorium masih sangat minim.

4) Kendala tata kelola tata laksana laboratorium IPA SMP di Kabupaten Buleleng.

Berdasarkan data hasil wawancara dengan kepala sekolah dan wawancara dengan guru IPA, angket guru, serta didukung oleh hasil observasi laboratorium, dapat dirumuskan kendala tata kelola dan tata laksana laboratorium sekolah untuk melaksanakan kegiatan praktikum. Kendala-kendala tersebut tersebut dapat dirumuskan sebagai berikut.

- Keterbatasan ruang laboratorium.

Permasalahan berkaitan dengan penggunaan ruang laboratorium menjadi semakin kompleks mengingat seluruh laboratorium yang ada di setiap sekolah sampel dipergunakan untuk ruang kelas.

- Keterbatasan fasilitas laboratorium.
- Keterbatasan alat-alat laboratorium. Permasalahan juga terjadi karena tidak tersedianya perangkat alat secara utuh.

- Keterbatasan bahan-bahan IPA. Bahan-bahan IPA yang tersedia di laboratorium lebih terbatas lagi dibandingkan alat-alat laboratoriumnya. Bahkan, beberapa sekolah tidak memiliki bahan-bahan IPA yang umum diperlukan dalam praktikum IPA.

- Tidak adanya tenaga laboran. Seperti disampaikan di depan, hanya $33,3 \%$ sekolah sampel didukung oleh tenaga laboran. Tidak adanya tenaga laboran juga berdampak laboratorium tidak terurus sehingga terkesan "terlantarkan".

- Ketiadaan jaminan keselamatan dan kesehatan pekerja laboratorium.

- Keterbatasan waktu efektif untuk tatap muka. Kurangnya waktu untuk menyelesaikan bahan, mendorong guru menggunakan metode ceramah atau diskusi dalam kegiatan belajar mengajarnya.

- Hambatan psikologis guru. Banyak guru merasa tidak puas mengajar jika belum banyak menyajikan informasi kepada siswa.

- Jumlah siswa dalam satu kelas yang relatif banyak menyebabkan praktikum susah dilaksanakan dengan baik, karena keterbatasan tenaga untuk melakukan bimbingan dan monitoring kinerja siswa, di samping kesulitan dalam penyediaan peralatan dan bahan-bahan yang diperlukan.

- Keterbatasan dana. Sumber dana yang pasti untuk kegiatan operasional sekolah hanya bersumber dari komite sekolah atau

Jurnal Pendidikan Indonesia |453 
dana BOS. Atas dasar itu, kegiatan kerja ilmiah IPA mesti dilakukan secara hemat, efektif, serta sebanyak mungkin menggunakan alat-alat dan bahan-bahan.

5) Kebutuhan-kebutuhan pengembangan kualitas tata kelola tata laksana laboratorium IPA SMP di Kabupaten Buleleng

Berdasarkan hasil analisis yang telah dipaparkan di atas, dapat dirumuskan kebutuhan-kebutuhan pengembangan kualitas tata kelola dan tata laksana laboratorium IPA SMP di kabupaten Buleleng adalah sebagai berikut.

- Untuk mengatasi masalah keterbatasan ruangan, dibutuhkan set kit alat yang portable (dapat dibawa ke kelas) sehingga tidak terpaku pada ruang laboratorium sebagai tempat praktikum.

- Dibutuhkan penyesuaian tata letak dan desain laboratorium. Selain itu, konstruksi laboratorium seharusnya juga memperhatikan kesehatan lingkungan.

- Guru mesti menyadari bahwa IPA merupakan ilmu berbasis eksperimen. Sejalan dengan itu, laboratorium dan praktikum tidak hanya merupakan pendukung pembelajaran IPA, tetapi menjadi bagian dari sistem akademik pembelajaran IPA. Guru mesti melakukan redefinisi terhadap pembelajaran IPA, yang tidak lagi berorientasi pada banyaknya materi yang mesti diinformasikan, tetapi menekankan kompetensi yang harus dikuasi siswa.

- Dibutuhkan Standar Operasional Prosedur (SOP) tata kelola dan tata laksana laboratorium yang terpola, terstruktur dan efektif untuk optimalisasi sumber daya manusia dan sumber daya penunjang yang ada di sekolah.

- Tata laksana dalam berlaboratorium sedapat mungkin disesuaikan dengan konteks lingkungan dan kebutuhan siswa serta memanfaatkan alat dan bahan alternatif yang bisa dengan mudah diperoleh dari lingkungan sekolah/siswa.

Produk/luaran dari penelitian ini adalah (1) SOP tata kelola dan tata laksana laboratorium IPA SMP, Artikel ilmiah, (3) proseding pada seminar ilmiah institusi.

\section{Pembahasan Hasil Penelitian}

Tata kelola laboratorium adalah proses pendayagunaan sumber daya laboratorium secara efektif dan efisien, untuk mencapai suatu sasaran yang secara optimal (Suyitno, A. 2010). Tata kelola laboratorium harus memperhatikan keberlanjutan fungsi sumber daya serta berdasar prinsip dan fungsi manajemen yang baik. Aspek pengelolaan lab meliputi : perencanaan, pengorganisasian/penataan, directing (pengaturan) pengendalian pengawasan budgeting/ anggaran.

Pengelolaan alat dan bahan merupakan suatu kegiatan yang ikut menentukan keberhasilan pendayagunaan laboratorium. Kelancaran kegiatan laboratorium akan sangat bergantung pada administrasi, penyimpanan, dan perawatan alat dan bahan (Depdikbud, 1995: 19).

Penataan terkait erat dengan pengelompokkan,penempatan, penyimpan-an dan kemudahan ditelusuri. Pemeliharaan dan pengJurnal Pendidikan Indonesia |454 
gunaannya alat-alat lab IPA dapat dikelompokkan ke dalam beberapa kategori, seperti : alat kegiatan (pengamatan \& pengukuran), alat-alat dasar, digunakan untuk melengkapi alat/perangkat alat percobaan, seperti gelas kimia, tabung reaksi, pipa kapiler, erlenmeyer, pelubang gabus, selang plastik); alat peraga seperti KIT IPA, termasuk di dalamnya model, torso, insektarium dan alat-alat lain yang serupa, digunakan untuk meragakan suatu struktur suatu obyek IPA, charta, foto, atau bagan, digunakan untuk menjelaskan suatu hal; perkakas dan alat penunjang seperti obeng, alat bor, tang, catut, gunting, soldier, alat pemadam kebakaran, jas lab, masker, kulkas, dst yang digunakan untuk memperbaiki macam-macam peralatan lab.

Guru IPA tampaknya masih memandang kegiatan berlaboratorium (praktikum)sebagai elengkap/penunjang kegiatan pembelajaran IPA, bukan sebagai bagian sistem akademik. Terbukti, dalam pembelajaran IPA guru lebih banyak menggunakan metode ceramah, tanya jawab, atau diskusi; sedangkan kompetensi yang disasar lebih banyak berkaitan dengan konsepkonsep prosedural eksperimentatif, yang mesti diajarkan dengan metode demonstrasi atau eksperimen. Fungsi laboratorium sebagai pelengkap menyebabkan fasilitasnya kurang mendapat perhatian, bahkan ruangannya pun dipergunakan sebagai ruang kelas atau ruang guru.

Jarangnya kegiatan laboratorium dapat ditengarai sebagai implikasi daripada bentuk soal ujian akhir yang sering dijadikan acuan oleh guru. Sistem penilaian yang sangat jarang mengukur penguasaan keterampilan proses sains menyebabkan guru enggan mengajar dengan berpraktikum.

Ada dua hal perlu dilakukan berkaitan dengan fenomena ini. Pertama, guru mesti menyadari bahwa IPA merupakan ilmu berbasis eksperimen. Sejalan dengan itu, laboratorium dan praktikum tidak hanya merupakan pendukung pembelajaran IPA, tetapi menjadi bagian dari sistem akademik pembelajaran IPA. Kedua, guru mesti melakukan redefinisi terhadap pembelajaran IPA, yang tidak lagi berorientasi pada banyaknya materi yang mesti diinformasikan, tetapi menekankan kompetensi yang harus dikuasi siswa. Atas dasar itu, guru mesti memilah dan memilih materi yang esensial diajarkan kepada siswa agar mereka menguasai kompetensi sesuai tuntutan kurikulum.

Kondisi daya dukung sekolah terhadap pembelajaran IPA SMP di kabupaten Buleleng secara umum masih kurang. Keberadaan guru IPA sudah memadai ditinjau dari kualifikasi akademiknya, tetapi kompetensi pengelolaan pembelajaran berlaboratorium masih perlu ditingkatkan, tenaga laboran masih minim bahkan hampir semua sekolah tidak memiliki tenaga laboran, sehingga seluruh beban kerja terkait dengan persiapan keperluan praktikum harus dilakukan oleh guru. Selain tidak adanya laboran, sekolah juga mengalami keterbatasan fasilitas alat dan bahan laboratorium.

Sekolah mengalami beberapa kendala dan hambatan untuk melaksanakan kegiatan praktikum dalam pembelajaran IPA. Kendala dan hambatan tersebut, di antaranya: keterbatasan ruang dan fasilitas 
laboratorium, keterbatasan alat-alat dan bahan-bahan IPA, ketidaktersedian tenaga laboran, ketidakmampuan guru mengelola pembelajaran sesuai dengan ketersediaan waktu efektif, hambatan psikologis guru yang belum merasa puas jika tidak menyampaikan banyak informasi dalam pembelajaran, ketiadaan jaminan keselamatan dan kesehatan pekerja laboratorium, dan kekurangan dana pendukung operasional.

Untuk mengatasi masalah keterbatasan ruangan, dibutuhkan set kit alat yang portable (dapat dibawa ke kelas) sehingga tidak terpaku pada ruang laboratorium sebagai tempat praktikum.Terhadap kasus pengalihfungsian ruang laboratorium sebagai ruang belajar, dapat diatasi dengan penjadwalan yang lebioh baik. Bahwa ruang laboratorium bisa dipakai ruang belajar hanya bagi kelas-kelas yang akan praktikum menggunakan laboratorium. Sebaliknya, kegiatan praktikum (demonstrasi) di kelas dapat dilakukan terutama untuk praktikum yang tidak menggunakan bahan-bahan berbahaya.

Terkait dengan persolan keselamatan dan kesehatan kerja di laboratorium, perlu dilakukan penataan ruang laboratorium sekaligus juga memperhatikan kesehatan lingkungan, misalnya saluran pembuangan air limbah laboratorium tidak boleh menyatu dengan saluran kamar mandi dan WC, serta ada pengolahan awal terhadap sisa/limbah bahan-bahan praktikum berbahaya dan beracun yang akan dibuang.

Sehubungan dengan kendala dana/biaya, sekolah mesti melakukan berbagai upaya, di antaranya pencarian sumber dana baru dengan berpartisipasi aktif pada berbagai proyek (grant) yang didanai oleh pemerintah, mencari subsidi dari organisasi non pemerintah yang tidak bersifat mengikat. Khusus keterbatasan waktu, guru mesti mengetahui materi-materi esensial yang harus diajarkan agar siswa mampu mencapai kompetensi yang hendak disasar dalam pembelajaran yang dilakukannya. Materi yang bersifat non esensial dapat dipelajari sendiri oleh siswa berdasarkan materi esensial yang sudah dikuasinya. Untuk itu, mestinya guru-guru lebih sering dilibatkan dalam kegiatan ilmiah yang dapat meningkatkan kompetensi dan atmosfer akademik.

Guru mesti menyadari bahwa IPA merupakan ilmu berbasis eksperimen. Sejalan dengan itu, laboratorium dan praktikum tidak hanya merupakan pendukung pembelajaran IPA, tetapi menjadi bagian dari sistem akademik pembelajaran IPA. Guru mesti melakukan redefinisi terhadap pembelajaran IPA, yang tidak lagi berorientasi pada banyaknya materi yang mesti diinformasikan, tetapi menekankan kompetensi yang harus dikuasi siswa.

Untuk keteraturan dan ketertiban pengguna laboratorium dalam memanfaatkan lab, dibutuhkan Standar Operasional Prosedur (SOP) tata kelola dan tata laksana laboratorium yang terpola, terstruktur dan efektif. Dengan mempertimbangkan kondisi riil sekolah dan lingkungannya, Standar Operasional Prosedur (SOP) tata kelola laboratorium mestinya dapat mengoptimalkan sumber daya manusia dan sumber daya penunjang yang ada di sekolah. Dengan demikian, 
pemanfaatan laboratorium untuk kegiatan praktikum bisa terpola, terstruktur, dan efektif.

Tata laksana dalam berlaboratorium sedapat mungkin disesuaikan dengan konteks lingkungan dan kebutuhan siswa serta memanfaatkan alat dan bahan alternatif yang bisa dengan mudah diperoleh dari lingkungan sekolah/siswa. Selanjutnya, dibutuhkan petunjuk praktikum yang sedapat mungkin disesuaikan dengan konteks lingkungan dan kebutuhan siswa. Memanfaatkan alat dan bahan alternatif yang bisa dengan mudah diperoleh dari lingkungan sekolah/siswa. Pengadaan set/kit alat sederhana yang dilengkapi petunjuk teknis pelaksanaan praktikum diharapkan dapat mengatasi kendala kekurangan ruang dan waktu yang selama ini banyak dijadikan alasan untuk tidak memanfaatkan laboratorium dalam pembelajaran IPA.

\section{SIMPULAN DAN SARAN}

\section{Simpulan}

Berdasarkan hasil penelitian dan pembahasan yang telah dipaparkan di atas, dapat dirumuskan simpulan sebagai berikut.

- Dimensi-dimensi yang perlu mendapat perhatian dalam tata kelola dan tata laksana laboratorium IPA di SMP mencakup: perencanaan, penataan, pengadministrasian, pengamanan, perawatan, dan pengawasan.

- Kondisi daya dukung SDM dan sarana-prasarana laboratorium untuk menunjang kegiatan pembelajaran IPASMP di Kabupaten Buleleng relative masih minim.
- Pengelolaan dan pelaksanaan kegiatan laboratorium pada pembelajaran IPA SMP di Kabupaten Buleleng masih perlu ditingkatkan.

- Sejumlah kendala/hambatan yang dihadapi sekolah untuk melaksanakan tata kelola tata laksana laboratorium, yaitu: keterbatasan ruang dan fasilitas laboratorium, keterbatasan alat-alat dan bahan-bahan praktikum, ketidaktersediaan tenaga laboran, belum ada SOP tata kelola tata laksana laboratorium, ketidakmampuan guru mengelola pembelajaran sesuai dengan ketersediaan waktu efektif, hambatan psikologis guru yang belum merasa puas jika tidak banyak berceramah selama pembelajaran, tidak adanya jaminan keselamatan dan kesehatan pekerja laboratorium, dan keterbatasan dana pendukung operasional.

- Upaya untuk meningkatkan kualitas tata kelola tata laksana laboratorium IPA SMP di Kabupaten Buleleng antara lain: pengembangan Standar Operasional Prosedur (SOP) tata kelola dan tata laksana laboratorium yang terpola, terstruktur, praktis dan efektif. SOP tata kelola laboratorium IPA SMP yang dapat mengoptimalkan sumber daya manusia dan sumber daya penunjang yang ada di sekolah. Tata laksana laboratorium sedapat mungkin disesuaikan dengan konteks lingkungan, kebutuhan siswa, dan kondisi sekolah.

\section{Saran}

Untuk mengatasi kendala/hambatan yang dihadapi sekolah dalam tata kelola

Jurnal Pendidikan Indonesia |457 
dan tata laksana laboratorium IPA, dapat disarankan sebagai berikut.

- Untuk menanggulangi keterbatasan alat/bahan praktikum, perlu ada perhatian lebih sungguh-sungguh dari pihak pengelola laboratorium maupun kepala sekolah dalam hal penyesuaian alokasi dana anggaran pengadaan sarana kegiatan praktikum. Realisasi programprogram untuk meningkatkan efektifitas dan optimalisasi pemanfaatan laboratorium dalam pembelajaran IPA.

- Bagi guru IPA disarankan untuk memikirkan upaya-upaya alternatif sebagai pengganti bahan/alat yang tidak tersedia, misalnya pemanfaatan lingkungan sebagai sumber bahan praktikum. Perlu ada perubahan paradigma dalam pembelajaran IPA.

- Bagi pihak pemerintah (terkait), disarankan bahwa perlu dilakukan rekrutmen tenaga laboran untuk ditugaskan di laboratorium IPA SMP.

- Untuk mengefektifkan pemanfaatan laboratorium, perlu dilengkapi dengan standar operasioanl prosedur (SOP) tata kelola dan tata laksana laboratorium, untuk itu disarankan di tiap-tiap laboratorium agar dilengkapi dengan Standar Operasional Prosedur (SOP) tata kelola dan tata laksana laboratorium.

\section{UCAPAN TERIMAKASIH}

Ucapan terima kasih disampaikan kepada pihak Lembaga Penelitian Undiksha yang telah mendanai penelitian ini. Ucapan terima kasih juga disampaikan kepada pihak sekolah (kepala sekolah, pengelola laboratorium IPA, guru IPA, Laboran, bagian sarana prasarana sekolah) terutama bagi sekolah-sekolah yang dijadikan sampel penelitian.

\section{DAFTAR PUSTAKA}

BSNP (Badan Standar Nasional Pendidikan). 2006. Standar Sarana dan Prasarana Sekolah/Madrasah Pendidikan Umum. Jakarta.

Berte, L.M. 2012. Quality Management System: A Model for Laboratory Services; Approved Guideline. Fourth Edition. 2012 Clinical and Laboratory Standards Institute. ISBN Number: 1-56238-761-8

Koretsky, M. at.al. 2011. Student Perceptions of Learning in the Laboratory: Comparison of Industrially Situated Virtual Laboratories to Capstone Physical Laboratories. Journal of Engineering Education. July 2011, Vol. 100, No. 3, pp. 540-573. http://www.jee.org: diakses tgl. 2 Setember 2012.

Krajcik, J. S. and Banaszak Holl, M. M. 2012. Concurrent Enrollment in Lecture and Laboratory Enhances Student. Journal of Research in Science Teaching. Vol 49 Issue 5. May 2012. ISSN 0022-4308. online www/htt: library.wiley.com/ doi/10.1002/ tea.21016. diakses tgl. 2 September 2012.

Mundilarto. 2007. Konsep dan Prinsip Pengelolaan Laboratorium IPA. Makalah disampaikan pada Diklat Tenaga Fungsional Laboran IPA pada P4TK dan LPMP di seluruh Indonesia. Jakarta.

Novianti, N.R. 2011. Kontribusi Pengelolaan Laboratorium dan Jurnal Pendidikan Indonesia |458 
Motivasi Belajar Siswa Tehadap Efektifitas Proses Pembelajaran (Penelitian pada SMP Negeri dan Swasta di Kabupaten Kuningan Provinsi JawaBarat).

Jurnal.Upi.Edu/File/15. Edisi Khusus No. 1, Agustus 2011. ISSN 1412-565X

PP Nomor 19 Tahun 2005 tentang Standar Nasional Pendidikan. Depdiknas.

Permanasari Anna, 2007. Pengelolaan Laboratorium IPA. Makalah. Disampaikan pada Technical Assistance Pengelolaan Laboratorium IPA di Program Pendidikan IPA FMIPA UNDIKSA.

Sidharta, A., dkk. 2007. Studi Penelusuran Kinerja Laboratorium Sebagai Analisis Keefektifan Pengelolaan Laboratorium IPA-Kimia LPMP. Pusat Pengembangan dan Pemberdayaan Pendidik dan Tenaga Kependidikan IImu Pengetahuan Alam. Bandung. Tidak dipublikasikan.
Steers, Richard M. et al. 1985. Efektivitas Organisasi. Jakarta: Erlangga.

Subamia, I.D.P. $2011 . \quad$ Optimalisasi Eksistensi Laboratorium Pendidikan sebagai Wahana Strategis Revitalisasi Pendidikan Karakter Berlandaskan Kearifan Lokal. Proceeding Seminar Nasional MIPA ISBN 978-6028310-76-5. Th.2012.

Subamia, I.D.P, dkk. 2012. Pelatihan Keterampilan Dasar Laboratorium (Basic Skill Laboratory) Bagi Staf Laboraorium IPA SMP SeKabupaten Buleleng. Jurnal Pengabdian Kepada Masyarakat Widya Laksana. Undiksha: ISSN: 1410-4369, Edisi Juli 2012.

Sulastri, S. 2008. Identifikasi Kondisi Laboratorium IPA dan Penggunaannya di SMP Negeri di Wilayah Jakarta Selatan. Jurnal Lingkar Mutu Pendidikan. Volume I. 